\title{
MEASUREMENT OF FATIGUE IN CHILDREN AND ADOLESCENTS WITH CANCER: AN INTEGRATIVE REVIEW
}

\author{
Michelle Darezzo Rodrigues Nunes ${ }^{1}$, Michele Cristina Miyauti Silva², Ester Leonardo Rocha ${ }^{3}$, Regina \\ Aparecida Garcia de Lima4, Lucila Castanheira Nascimento ${ }^{5}$
}

\footnotetext{
${ }^{1}$ Doctoral Studant, Graduate Program in Public Health Nursing, University of São Paulo (USP) at Ribeirão Preto College of Nursing (EERP), FAPESP grantee. São Paulo, Brasil. E-mail: mid13@hotmail.com

${ }^{2}$ Master's student, Graduate Program in Public Health Nursing at EERP/USP. E-mail: mimicris@hotmail.com

${ }^{3}$ Undergraduate Nursing Student at EERP/USP. CNPq grantee. São Paulo, Brasil. E-mail: ester.rocha@usp.br

${ }^{4}$ Ph.D. in Nursing. Full Professor, Maternal-Infant and Public Health Nursing Department at EERP/USP. CNPq researcher. E-mail: limare@eerp.usp.br

${ }^{5}$ Ph.D. in Nursing. Associate Professor, Maternal-Infant and Public Health Nursing Department at EERP/USP. CNPq researcher. E-mail: lucila@eerp.usp.br
}

\begin{abstract}
This study analyzed scientific production on the measurement of fatigue in children and adolescents with cancer, particularly the instruments used. Integrative review, searching in PubMed, PsycINFO, Web of Science, CINAHL, LILACS, SciELO, IBECS and COCHRANE, without any time restriction, using key words and descriptors in different combinations. The review sample comprised 21 references. The results composed two categories: instrument development and validation and fatigue measurement. American nurses developed most studies, between 2002 and 2011, using two scales. The studies assessed the children and adolescents' self-reports and the parents' reports. They also associated fatigue with sleep pattern, quality of life, depression, survival and dexamethasone use. The importance of research on this theme is evidenced, including studies that apply these instruments in practice. The gap in knowledge production on this theme is highlighted in the Brazilian context.
\end{abstract}

KEYWORDS: Child. Adolescent. Fatigue. Neoplasms. Pediatric nursing.

\section{MENSURAÇÃO DE FADIGA EM CRIANÇAS E ADOLESCENTES COM CÂNCER: REVISÃO INTEGRATIVA}

RESUMO: O estudo analisou a produção científica relativa à mensuração de fadiga em crianças e adolescentes com câncer, com destaque aos instrumentos utilizados. Revisão integrativa, com busca no PubMed, PsycINFO, Web of Science, CINHAL, LILACS, SciELO, IBECS e COCHRANE, sem restrição de período, utilizando-se palavras-chave e descritores, em várias combinações. A amostra de revisão foi constituída de 21 referências. Os resultados compuseram duas categorias: desenvolvimento e validação de instrumentos e mensuração da fadiga. A maioria dos estudos foi desenvolvida por enfermeiros americanos, entre 2002 e 2011, utilizando-se duas escalas. Os estudos avaliaram os autorrelatos das crianças e adolescentes e relato dos pais. Eles também associaram a fadiga ao padrão de sono, qualidade de vida, depressão, sobrevida e uso de dexametasona. Evidencia-se a importância do desenvolvimento de estudos nessa temática, incluindo aqueles com aplicação desses instrumentos na prática. Salienta-se a lacuna na produção de conhecimento neste tema no contexto brasileiro.

PALAVRAS CHAVE: Criança. Adolescente. Fadiga. Neoplasias. Enfermagem pediátrica.

\section{MEDICIÓN DE LA FATIGA EN NIÑOS Y ADOLESCENTES CON CÁNCER: REVISIÓN INTEGRATIVA}

RESUMEN: El estudio analizó la producción científica sobre medición de fatiga en niños y adolescentes con cáncer, con destaque en los instrumentos que fueron utilizados. Revisión integrativa, con búsqueda en las bases de datos PubMed, PsycINFO, Web of Science, CINAHL, LILACS, SCIELO, IBECS y COCHRANE, sin restricción de período, utilizándose palabras-clave y descriptores, en varias combinaciones. La muestra incluyó 21 referencias. Los resultados compusieron dos categorías: Desarrollo y validación de instrumentos y Medición de la fatiga. La mayoría de los estudios fue desarrollada por enfermeros americanos, entre 2002 y 2011, utilizándose dos escalas. Los estudios evaluaron los auto-relatos de los niños y adolescentes y los relatos de los padres. También asociaron la fatiga con patrón de sueño, calidad de vida, depresión, sobrevida y uso de dexametasona. Se evidencia la importancia de estudios sobre esa temática, incluyendo la aplicación práctica de esos instrumentos. Se destaca el vacío en la producción de conocimiento en este tema en el contexto brasileño. PALABRAS CLAVE: Niño. Adolescente. Fatiga. Neoplasias. Enfermería pediátrica. 


\section{INTRODUCTION}

Fatigue is a subjective and diffuse experience that involves physical, cognitive and psychological aspects. It can be acute, when extreme tiredness is described as a result of physical or mental stress, improving through rest; or chronic, when it does not improve through rest and functionality is lost. ${ }^{1}$ It has been widely indicated as a highly prevalent symptom that affects cancer patients in the different phases of the diagnostic-therapeutic process, ${ }^{1-2}$ and is one of the most anguishing symptoms ${ }^{3-6}$ and the most weakening in advanced cancer patients. ${ }^{1}$ Reports by parents and health professionals classify it as a moderate to severe symptom in children and adolescents undergoing cancer treatment. ${ }^{7}$

Causes of fatigue in cancer patients can be associated with the hypermetabolic state linked to the growth of the tumor; competition for nutrients between the organism and the tumor; harmful effects of the chemotherapy and radiotherapy; inadequate nutritional intake, associated with nausea and vomiting due to the antineoplastic therapy; anemia; sleep disorders; uncertainty about the future; fear of death and mutilations. ${ }^{8}$

Few quantitative studies have addressed the theme in pediatric oncology patients ${ }^{9}$ or examined the etiology of chemotherapy-associated fatigue, ${ }^{10}$ or fatigue management. In addition, the need to educate professionals, patients and caregivers is observed with a view to its identification and treatment. ${ }^{1}$

For the pediatric age range, considering that the oncologic treatment is aggressive and curecentered, physicians may ignore side effects like fatigue $^{11}$ or consider them as inevitable symptoms the patients need to bear. ${ }^{7}$ Hence, often, the fatigue ends up being underestimated due to the lack of a well-established concept, appropriate symptom assessment and measurement instruments, insufficient reports of discomfort by the patients and low priority by the professionals..$^{9}$ The objective in this study was to analyze the Brazilian and international scientific production related to the available instruments to measure fatigue in child and adolescent cancer patients. The researchers believe that instructing health professionals to assess this symptom can mobilize them towards a better clinical practice.

\section{METHOD}

An integrative review was undertaken, which consists of a comprehensive literature analysis that joins and summarizes publications, contributing to understand a particular problem and providing support to evidence-based practice through grounded knowledge. ${ }^{12}$ We delimited the following phases: formulation of the problem (elaboration of guiding question, key words and inclusion criteria): search procedures (inclusion of relevant literature about the theme of interest); assessment of data (extraction of relevant information from selected articles); data analysis and interpretation (data integration process) and presentation of review (synthesis to illustrate the data integration process). ${ }^{13}$ The guiding question of the review was: "what specific instruments are available to measure fatigue in children or adolescents with cancer?".

The following databases were investigated: PUBMED; PSYCInfo; Web of Science and CINHAL; besides the research in the Virtual Health Library, through the General Health Sciences interface, which comprises databases and electronic libraries: LILACS; IBECS, Spanish Bibliographic Index in Health Sciences; MEDLINE; the Cochrane Library and SciELO. The following descriptors were used, identified in DECs (Health Science Descriptors) and MESH (Medical Subject Headings): fatigue, child, adolescent, instrument, and the key words: scale and cancer, in different combinations. The inclusion criteria were: original papers, theses and dissertations, whose theme answered the guiding question, published without time limit, in English, Portuguese or Spanish. The exclusion criteria were: instruments that simultaneously measured multiple symptoms, including fatigue; focused on adult populations and on diseases different from cancer. After the search, about 1000 studies were identified, whose titles and abstracts the authors read exhaustively and independently, so as to guarantee rigor in the selection of the articles that responded to the guiding question of the review and complied with the established inclusion and exclusion criteria. Finally, 52 studies were selected for reading of the full papers.

The articles were assessed according to the following variables, which constituted the instrument the authors elaborated to extract the data: country of origin and activity area of the authors, publication year, age and number of subjects, information source (self-report by children and/ or adolescents and/or parents' report), type of diagnosis, instruments used, application time and instrument limitations identified by the authors. Next, the data were grouped through qualitative analysis, which permitted the identification of similarities and the elaboration of two categories: 
'Development and validation of instruments that measure fatigue' and 'Measurement of fatigue'.

\section{RESULTS}

Thirty-one of the 52 abstracts identified for detailed reading were excluded because generic instruments were used $(\mathrm{N}=8)$, because the population did not consist of children/adolescents and/ or cancer patients $(\mathrm{N}=9)$ or because they did not focus on topics related to the research $(\mathrm{N}=14)$. The final review sample included 21 studies.

\section{Characteristics of the studies}

As regards the country of origin, seven studies came from the United States, two from Brazil, two from Greece, two from Canada, one from Turkey and seven were studies that involved international cooperation. As to the activity area of the researchers involved in the studies, great multidisciplinarity is observed, as one of the studies addressed fatigue from the perspective of medicine and architecture; in two studies, the researchers were active in medicine, nursing and biostatistics; in another, the researchers worked in medicine, nursing, biostatistics and pharmaceutical sciences. Most researchers involved in the studies came from nursing (7) and medicine (6). The year of publication varied from 2002 to 2011, with one article from 2002, one from 2003, one from 2004, four from 2007, five from 2008, two from 2009, four from 2010 and three from 2011. The fatigue assessment instruments used in the studies were: PedsQL Multidimensional Fatigue Scale (5), Fatigue Scale-Child, Fatigue Scale-Adolescent, Fatigue Scale-Parent e Fatigue Scale-Staff, separately or in combination (14), Fatigue Visual Analogue Scale in combination with the Fatigue Scale-Adolescent and Fatigue Scale-Parent (1), Pediatric Functional Assessment of Chronic Illness Therapy-Fatigue, in combination with the Multidimensional Fatigue Scale (1).

The 21 studies were grouped in two main research foci, which were: (1) development and validation of instruments that measure fatigue, comprising seven studies, and (2) measurement of fatigue, including 14 studies.

\section{Development and validation of instruments that measure fatigue}

This focus included all studies aimed at the development and/or semantic or psychometric validation of fatigue assessment instruments in children and adolescents with cancer. Seven of the 21 studies belong to this category, two of which developed and validated and instrument, while five were validation studies.

The study by Varni et al. ${ }^{9}$ was aimed at presenting the measurement properties of the Pediatric Quality of Life Inventory (PedsQL) in childhood cancer, informing the reliability and validity of the following scales: PedsQL Generic Core, PedsQL Cancer Module, PedsQL Multidimensional Fatigue Scale. The three scales were applied to 339 families, with 220 self-reports by the children and 337 reports from parents $(85 \%$ mothers), administered simultaneously, but separately to children and parents. The results demonstrate the reliability and validity of the three scales in children with cancer. It was concluded that the PedsQL can be used as an outcome measure in clinical studies, research and clinical practice. ${ }^{9}$

The PedsQL ${ }^{\text {TM }}$ Multidimensional Fatigue Scale (PedsQL-MFS) was developed by Varni et al., ${ }^{9}$ in English; it consists of three subscales (general fatigue: self/rest-related, and cognitive fatigue). The instrument uses a five-point Likert scale, which is transformed into a scale from zero to $100(1=100,2=75,3=50,4=25,5=0)$. Higher scores indicate less fatigue symptoms. This instrument has a specific version for self-reports by children and adolescents, divided per age range (5-7 years; $8-12$ years; 13 to 18 years) and a version for reports from parents (2-18 years). It also has standard and acute versions that assess fatigue related to the last month or the last week, respectively. The instrument is used in different languages today, including Brazilian Portuguese. ${ }^{14}$

Five studies developed and/or validated the following fatigue assessment instruments: Fatigue Scale-Child (FS-C), ${ }^{15-17}$ Fatigue Scale-Adolescent (FS-A), ${ }^{18-19}$ Fatigue Scale-Parent FS-P), ${ }^{17}$ Fatigue Scale-Staff (FS-S) ${ }^{17}$ created by the same research group, led by Hockenberry et al. ${ }^{17}$ and Hinds et al. ${ }^{19}$ Three of these five studies refer to the validation of the instrument in the language it was created in (English), and two to the semantic or psychometric validation of the FS-C and FS-A for the Chinese language and culture.

The study that aimed to develop and test three instrument to measure fatigue in children with cancer, one from the child's perspective, another from the parents' view and the third from health professionals' perspective, was developed in English by Hinds and Hockenberry, in 2003. 
The participants were 149 children, between seven and twelve years of age, about to receive chemotherapy for cancer, 147 parents and 124 professionals. The study consisted of three phases: instrument development; content validation and estimates of psychometric properties of the three instruments. They were named as follows: Fatigue Scale-Child (FS-C), Fatigue Scale-Parent (FS-P), Fatigue Scale-Staff (FS-S) and demonstrated validity and reliability. That was the first study to offer valid and reliable instruments to measure fatigue in children with cancer. ${ }^{17}$

The Fatigue Scale Child (FS-C) was developed by Hockenberry-Eaton et al. ${ }^{17}$ It is used to measure fatigue in children between seven and 12 years old through self-reported. The scale consists of 14 items that describe the intensity of fatigue during the previous week, based on a five-point Likert scale. The intensity classification varies between 14 (no fatigue) and 70 (high fatigue).

The Fatigue Scale-Parent (FS-P), developed by Hockenberry-Eaton et al., ${ }^{17}$ consists of 17 items about the parents' perception about the intensity of their children's fatigue in the last week, using a five-point Likert scale. The classification of the fatigue intensity varies between 17 (no fatigue) and 85 (high fatigue).

The Fatigue Scale-Staff (FS-S), also developed by Hockenberry-Eaton et al., ${ }^{17}$ consists of nine items, which explore the health professionals' perceptions about the intensity of fatigue in children during the last week. It uses a five-point Likert scale, and the classification ranges between nine (no fatigue) and 36 (high fatigue).

The authors also developed the version of the above scale for adolescents. ${ }^{19}$ The study involved two phases: 1 . Development of the instrument and 2. Test of the instrument, totaling four distinct studies. The final sample of the four studies involved 64 adolescents undergoing curative treatment for care, 61 parents and 18 health professionals (nurses). The adolescents completed the Fatigue Scale-Adolescent (FS-A), between two and four times, at key points in the treatment, which could be related to the hospitalization data, to the chemotherapy dates or to the application of dexamethasone. The results indicated the strong internal consistency and moderate to strong construct validity of the FS-A for a new research instrument. ${ }^{19}$

The Fatigue Scale Adolescent (FS-A) was developed by Hinds et al. ${ }^{19}$ This self-reporting instrument was projected to measure fatigue in adolescents between 13 and 18 years of age. It consists of 14 items that describe the fatigue intensity during the previous week, using a five-point Likert scale. The classification of the fatigue intensity ranges from 14 (no fatigue) to 70 (high fatigue).

With a view to developing and assessing the psychometric properties of the Chinese version of the Fatigue Scale-Children (FS-CC), some authors developed psychometric tests of the FS-CC, which included: internal consistency; content validity; construct validity; convergent validity; criterion validity and known-group validity, in a sample of 108 pediatric oncology patients in Taiwan, between 7 and 12 years of age. The results indicated that the FS-CC is a valid and reliable instrument to determine the intensity of cancer-related fatigue in children. ${ }^{15}$

In a subsequent study, the authors examined the semantic, conceptual and normative equivalence of the Chinese version of the Fatigue ScaleAdolescent (FS-AC), in relation to the original version of the scale (Fatigue Scale- Adolescent - FS-A). The study involved the following steps: translation of the instrument to Chinese, by five different translators: back-translation to the original language by three other translators who were not familiar with the instrument; review of translations and semantic equivalence by three experts. The new version of the instrument was applied to 51 oncology patients between 13 and 18 years of age and, in the results, the semantic, appropriate conceptual and normative equivalence was identified, as well as appropriate internal consistency and moderate to high content validity. The instrument showed to be reliable and valid. ${ }^{18}$

The final validation study, in which the original authors validated the Fatigue Scale-Child (FS-C), was aimed at identifying the most sensitive and specific score of that instrument. The subjects were 221 children with cancer under treatment. The results provided a guide for health professionals to interpret the fatigue scores, favoring specific interventions for its management in pediatric cancer patients. ${ }^{16}$

To report the reliability and validity of the Pediatric Functional Assessment of Chronic Illness Therapy-Fatigue (pedsFACIT-F) with different fatigue levels, an instrument was developed, validated and compared with the PedsQL Multidimensional Fatigue Scale (MFS). Therefore, the sample consisted of 159 cancer patients, between 8 and 18 years of age, who were invited to complete the pedsFACIT-F and PedsQL Multidimensional 
Fatigue Scale (MFS). The scores found on the pedsFACIT-F were correlated with the PedsQL-MFS scores; Evidence of satisfactory reliability and validity, appropriate internal consistency and the ability to distinguish three distinct fatigue levels were found. ${ }^{20}$

The PedsFACIT-F was elaborated based on 51 items in the Pediatric Fatigue Item-Bank (pedsFIB), developed through a literature review; patient and parent interaction; clinical assessment and multidisciplinary meetings. This one-dimensional scale consists of 11 items that assess fatigue in the previous seven days, using a five-point Likert scale, with zero indicating "never" and four "all the time".

\section{Fatigue measurement}

In this category, all studies were included that used specific instruments to measure fatigue in children and/or adolescents with cancer, totaling 14 studies, including 12 papers, one doctoral dissertation and one master's thesis. Figure 1 displays a summary of these studies.

With regard to the study population, seven studies used children and adolescents between 2 and 18 years and their parents as research subjects; ${ }^{21-27}$ four used only children and adolescents, ${ }^{28-31}$ one only used adolescents (13 to 18 years of age) as the subjects; ${ }^{32}$ one study only used parents of children and adolescent ${ }^{33}$ and another only children between 7 and 12 years old. ${ }^{34}$ The number of subjects varied in the samples: when only children were studied, the sample varied between $40^{34}$ and 100 children,; ${ }^{25}$ in case the sample only included adolescents, it varied between nine ${ }^{26}$ and $72,{ }^{28}$ when the sample included children and adolescents, it varied between $22^{31}$ and $100^{29}$ and, when the parents answered the instruments, the number varied between $53^{26}$ and 258 parents. ${ }^{22}$

The most prevalent types of cancer were leukemias. ${ }^{21-23,25-26,29-31}$ Three studies used only leukemia patients, ${ }^{22,25,31}$ one associated leukemia and brain tumor ${ }^{22}$ and one leukemia and solid tumor. ${ }^{30}$ Five studies ${ }^{24,27,32-34}$ presented a population with different cancer diagnoses, two of which excluded only patients with brain tumors ${ }^{24,32}$ and two included only children and adolescents without chances of cure. ${ }^{28,33}$

As regards the fatigue measuring instruments, nine studies used the instruments: Fatigue Scale-Child, Fatigue Scale-Adolescent and/or Fatigue Scale-Parent, separately or in combina- tion, ${ }^{21,23-26,28,30-32}$ while five studies used the PedsQL Multidimensional Fatigue Scale. ${ }^{22,27,31,33-34}$ Besides fatigue-related instruments, most of the studies (12) used other instruments or a combination of devices. Eight of them were related to the assessment of sleep patterns, , $3,25-27,29-30,32,34$ including the Actigraph, 23,25,29-30,34 the General Sleep Disturbance Scale (GSDS) (parents' report about their own sleep $)^{26,32}$ and Polysomnography. ${ }^{27}$ In combination with the PedsQL Multidimensional Fatigue Scale, three out of five studies conciliated the PedsQL Quality of Life Inventory - generic module and specific cancer module. The Beck inventory was also used in two studies. ${ }^{27-28}$ Other instruments were used in combination in one study: Memorial Symptom Assessment Scale (MSAS) ${ }^{28}$ Children's Sleep Habits Questionnaire (CSHQ) (the parents answered about their children's sleep), Fatigue Visual Analogue Scale (parents' report about their own fatigue) ${ }^{26}{ }^{26}$ Children's OMINIWalk/Run Scale and Physical Activity Log. ${ }^{31}$ Two studies only used the fatigue measurement instrument. ${ }^{21,34}$

As regards the semantic and psychometric validation of the instruments used, most of the studies cited that the instrument was previously validated for the native language of the study population. $21,23-24,26-27,30,32-34$ Three studies did not provide information about the instrument validity. ${ }^{25,28-29}$ Three reported on the validity and reliability of the instruments, obtained from earlier studies..$^{26,32,33}$ In two studies, the reliability of the fatigue scale was presented through Cronbach's alpha coefficient. ${ }^{28-29}$ In two other studies, besides Cronbach's alpha, the face, content and construct validity were informed. ${ }^{23,30}$ Two studies described that the semantic validation of the instruments was obtained for the Greek language, involving the translation, back-translation, expert committee and application in the population, but no mention was made of the instruments' psychometric validation. ${ }^{24,30}$ In the thesis analyzed, ${ }^{27}$ it was informed that the PedsQL MFS has been translated and validated for Brazilian Portuguese.

Regarding the time to apply the instruments, only two studies ${ }^{29-30}$ indicated that the expected duration was six to eight minutes for the Fatigue Scale-Child, three to four minutes for the Fatigue Scale-Adolescent, seven to 10 minutes for the Fatigue Scale-Parent, and less than four minutes for the Fatigue Scale-Staff.

Concerning the instrument limitations, the authors of six studies did not mention this information. $22,26-28,30-31$ Only three addressed specific 
limitations of the instruments used, ${ }^{21,24,34}$ which were: difficulty to distinguish among the fatigue levels and absence of a borderline value to distinguish between mild, moderate or severe fatigue. Other limitations found involved: restricted num- ber of participants, ${ }^{25,29,32}$ different diagnoses and treatment protocols; $;$;4,32,34 difficulty to find patients in palliative care ${ }^{33}$ and lack of participation of participants according to gender, which the authors believe influenced the fatigue scores. ${ }^{23}$

\section{Figure 1 - Articles included in the review according to author and country of origin, study focus, sample and instruments used, 2011}

\begin{tabular}{|c|c|c|c|}
\hline $\begin{array}{c}\text { Author/Year/Origin/ } \\
\text { Area } \\
\end{array}$ & Study objective & Sample & Fatigue instrument used \\
\hline $\begin{array}{l}\text { Meeske K, et al, } 2004^{22} \\
\text { United States } \\
\text { Medicine and } \\
\text { Architecture }\end{array}$ & $\begin{array}{l}\text { Verify the fatigue scores } \\
\text { in pediatric patients with } \\
\text { Brain Tumor and Acute } \\
\text { Lymphoblastic Leukemia (ALL) } \\
\end{array}$ & $\begin{array}{l}86 \text { parents of children between } 2 \\
\text { and } 18 \text { years old, with brain tumor; } \\
170 \text { parents of children between } 2 \\
\text { and } 18 \text { years old, with ALL } \\
\end{array}$ & $\begin{array}{l}\text { PedsQL Multidimensional Fatigue } \\
\text { Scale (parents' report) } \\
\text { PedsQL Generic Core } \\
\text { PedsQL Cancer Module } \\
\end{array}$ \\
\hline $\begin{array}{l}\text { Kurashima AY, } 2007^{28} \\
\text { Brazil } \\
\text { Nursing }\end{array}$ & $\begin{array}{l}\text { Validate prediction score of } \\
\text { survival time in children and } \\
\text { adolescents without chance of } \\
\text { cure } \\
\text { Assess the impact of symptoms } \\
\text { like fatigue, depression and } \\
\text { quality of life }\end{array}$ & $\begin{array}{l}17 \text { children between } 7 \text { and } 12 \text { years } \\
\text { old; } 11 \text { adolescents between } 13 \text { and } \\
18 \text { years old }\end{array}$ & $\begin{array}{l}\text { Fatigue Scale-Child } \\
\text { Fatigue Scale-Adolescent } \\
\text { Memorial Symptom Assessment } \\
\text { Scale (MSAS) } \\
\text { Beck Depression Inventory }\end{array}$ \\
\hline $\begin{array}{l}\text { Hinds PS, et al, } 2007^{29} \\
\text { United States, Canada, } \\
\text { Israel } \\
\text { Nursing, Medicine and } \\
\text { Biostatistics }\end{array}$ & $\begin{array}{l}\text { Determine the effect of } \\
\text { exposure to dexamethasone on } \\
\text { sleep and fatigue in pediatric } \\
\text { patients with ALL }\end{array}$ & $\begin{array}{l}100 \text { children between } 5 \text { and } 18 \\
\text { years old, from } 3 \text { different health } \\
\text { institutions }\end{array}$ & $\begin{array}{l}\text { Fatigue Scale Child } \\
\text { Fatigue Scale Adolescent } \\
\text { Fatigue Scale-Parent } \\
\text { Actigraph }\end{array}$ \\
\hline $\begin{array}{l}\text { Hinds PS, et al, } 2007^{30} \\
\text { United States } \\
\text { Nursing, Medicine and } \\
\text { Biostatistics. }\end{array}$ & $\begin{array}{l}\text { Describe night awakenings and } \\
\text { sleep interruptions of children } \\
\text { and adolescents undergoing } \\
\text { chemotherapy } \\
\text { Assess the relations between } \\
\text { sleep and fatigue } \\
\end{array}$ & $\begin{array}{l}25 \text { patients with solid tumors and } \\
4 \text { with Acute Myeloid Leukemia } \\
\text { (AML), between } 7 \text { and } 18 \text { years old }\end{array}$ & $\begin{array}{l}\text { Fatigue Scale Child } \\
\text { Fatigue Scale Adolescent } \\
\text { Actigraph }\end{array}$ \\
\hline $\begin{array}{l}\text { Sanford SD, et al, } \\
2008^{23} \\
\text { United States } \\
\text { Medicine }\end{array}$ & $\begin{array}{l}\text { Analyze the differences } \\
\text { in sleep, fatigue and daily } \\
\text { activities between genders }\end{array}$ & $\begin{array}{l}88 \text { children and their parents, } \\
\text { between } 5 \text { and } 17 \text { years old }\end{array}$ & \begin{tabular}{|l} 
Fatigue Scale-Child \\
Fatigue Scale-Adolescent \\
Fatigue Scale-Parent \\
Actigraph \\
\end{tabular} \\
\hline $\begin{array}{l}\text { Ekti GR et al, } 2008^{21} \\
\text { Turkey } \\
\text { Nursing }\end{array}$ & $\begin{array}{l}\text { Assess whether children who } \\
\text { received nursing interventions } \\
\text { presented less fatigue than the } \\
\text { control group }\end{array}$ & $\begin{array}{l}60 \text { children between } 7 \text { and } 12 \text { years } \\
\text { old, receiving chemotherapy ( } 30 \text { in } \\
\text { the experimental group and } 30 \text { in } \\
\text { the control group) and reports by } \\
\text { their parents }\end{array}$ & $\begin{array}{l}\text { Fatigue Scale-Child } \\
\text { Fatigue Scale-Parent }\end{array}$ \\
\hline $\begin{array}{l}\text { Perdikarus P, et al, } \\
2008^{34} \\
\text { Greece } \\
\text { Nursing }\end{array}$ & $\begin{array}{l}\text { Assess the variation in the } \\
\text { fatigue score during cancer } \\
\text { treatment } \\
\text { Describe the possible causes } \\
\text { of fatigue from the children's } \\
\text { viewpoints }\end{array}$ & $\begin{array}{l}40 \text { children between } 7 \text { and } 12 \text { years } \\
\text { old, with cancer, followed at an } \\
\text { oncology outpatient clinic of a } \\
\text { Greek hospital }\end{array}$ & Fatigue Scale-Child \\
\hline $\begin{array}{l}\text { Silva RZM, 200927 } \\
\text { Brazil } \\
\text { Medicine }\end{array}$ & $\begin{array}{l}\text { Assess fatigue } \\
\text { multidimensionally } \\
\text { Associate fatigue with } \\
\text { depressive symptoms and sleep } \\
\text { disorders } \\
\text { Assess the agreement between } \\
\text { adolescents and caregivers } \\
\end{array}$ & $\begin{array}{l}72 \text { adolescents between } 13 \\
\text { and } 18 \text { years old, submitted to } \\
\text { chemotherapy, radiotherapy, } \\
\text { surgery or its associations, and } \\
\text { their responsible caregivers }\end{array}$ & $\begin{array}{l}\text { PedsQL Multidimensional Fatigue } \\
\text { Scale (Self-report and parents' } \\
\text { report) } \\
\text { Beck Depression Inventory } \\
\text { Polysomnography }\end{array}$ \\
\hline $\begin{array}{l}\text { Perdikarus P, et al, } \\
2009^{24} \\
\text { Greece } \\
\text { Nursing }\end{array}$ & $\begin{array}{l}\text { Assess the variation in the } \\
\text { fatigue score during cancer } \\
\text { treatment according to the } \\
\text { children, adolescents and their } \\
\text { parents } \\
\text { Describe the possible causes of } \\
\text { fatigue from the perspective of } \\
\text { the children, adolescents and } \\
\text { their parents }\end{array}$ & $\begin{array}{l}40 \text { children between } 7 \text { and } 12 \\
\text { years; } 29 \text { adolescents between } \\
13 \text { and } 15 \text { years; with different } \\
\text { tumors, except for brain tumors, } \\
\text { and their parents }\end{array}$ & $\begin{array}{l}\text { Fatigue Scale-Child; } \\
\text { Fatigue Scale-Adolescent } \\
\text { Fatigue Scale-Parent }\end{array}$ \\
\hline
\end{tabular}




\begin{tabular}{|c|c|c|c|}
\hline $\begin{array}{c}\text { Author/Year/Origin/ } \\
\text { Area }\end{array}$ & Study objective & Sample & Fatigue instrument used \\
\hline $\begin{array}{l}\text { Zupanec S, et al, } 2010^{26} \\
\text { Canada } \\
\text { Nursing }\end{array}$ & $\begin{array}{l}\text { To describe the relations } \\
\text { between sleep disorders, sleep } \\
\text { habits and fatigue in children } \\
\text { submitted to chemotherapy } \\
\text { against ALL and their parents }\end{array}$ & $\begin{array}{l}64 \text { parents answered } \\
\text { questionnaires about their own } \\
\text { sleep and fatigue; } 9 \text { adolescents } \\
\text { answered questionnaires about } \\
\text { their own sleep and fatigue and } 53 \\
\text { parents answered questionnaires } \\
\text { about the sleep and fatigue of } \\
\text { their children and/or adolescents, } \\
\text { between } 4 \text { and } 18 \text { years of } \\
\text { age, suffering from ALL and } \\
\text { undergoing chemotherapy } \\
\end{array}$ & $\begin{array}{l}\text { Fatigue Scale-Adolescent } \\
\text { Fatigue Scale-Parent } \\
\text { Fatigue Visual Analogue Scale } \\
\text { (F-VAS) } \\
\text { Children's Sleep Habits } \\
\text { Questionnaire } \\
\text { General Sleep Disturbance Scale }\end{array}$ \\
\hline $\begin{array}{l}\text { Vallance K, et al, } 2010^{25} \\
\text { United States and } \\
\text { Canada } \\
\text { Nursing, Medicine, } \\
\text { Biostatistics and } \\
\text { Pharmacy } \\
\end{array}$ & $\begin{array}{l}\text { To investigate the influence of } \\
\text { dexamethasone on sleep and } \\
\text { fatigue, from the perspective of } \\
\text { children and their parents }\end{array}$ & $\begin{array}{l}100 \text { pediatric patients with ALL in } \\
\text { outpatient monitoring and their } \\
\text { parents }\end{array}$ & $\begin{array}{l}\text { Fatigue Scale-Child; } \\
\text { Fatigue Scale-Adolescent } \\
\text { Fatigue Scale-Parent } \\
\text { Actigraph }\end{array}$ \\
\hline $\begin{array}{l}\text { Erickson JM, et al, } \\
2011^{32} \\
\text { United States } \\
\text { Nursing, Medicine }\end{array}$ & $\begin{array}{l}\text { To measure fatigue, sleep } \\
\text { disorders and quality of } \\
\text { life in adolescents receiving } \\
\text { chemotherapy for more than } \\
\text { one month }\end{array}$ & $\begin{array}{l}20 \text { adolescents receiving } \\
\text { chemotherapy }\end{array}$ & $\begin{array}{l}\text { PedsQL Multidimensional Fatigue } \\
\text { Scale (self-report by adolescents) } \\
\text { General Sleep Disturbance Scale } \\
\text { PedsQL Generic Core } \\
\text { PedsQL Cancer Module }\end{array}$ \\
\hline $\begin{array}{l}\text { Tomlinson D, et al, } \\
2011^{33} \\
\text { Canada } \\
\text { Medicine }\end{array}$ & $\begin{array}{l}\text { To compare the quality of life } \\
\text { of children with cancer without } \\
\text { a reasonable chance of cure, } \\
6 \text { months or less before their } \\
\text { death and } 6 \text { months or more. }\end{array}$ & $\begin{array}{l}73 \text { parents of children with cancer, } \\
\text { without a reasonable chance of } \\
\text { cure, between } 2 \text { and } 18 \text { years of age }\end{array}$ & $\begin{array}{l}\text { PedsQL Multidimensional Fatigue } \\
\text { Scale (Report from parents) } \\
\text { PedsQL Generic Core } \\
\text { PedsQL Cancer Module }\end{array}$ \\
\hline $\begin{array}{l}\text { Yeh } \mathrm{CH} \text {, et at, } 2011^{31} \\
\text { China and United } \\
\text { States } \\
\text { Nursing }\end{array}$ & $\begin{array}{l}\text { Examine the feasibility of a } \\
\text { nursing intervention based on } \\
\text { exercises to reduce the fatigue } \\
\text { of children with ALL }\end{array}$ & $\begin{array}{l}12 \text { children in the intervention } \\
\text { group and } 10 \text { in the control group, } \\
\text { under } 18 \text { years of age, paired per } \\
\text { age and gender }\end{array}$ & $\begin{array}{l}\text { PedsQL Multidimensional Fatigue } \\
\text { Scale (self-report) } \\
\text { Children's OMNI Walk/Run Scale } \\
\text { Physical Activity Log }\end{array}$ \\
\hline
\end{tabular}

\section{DISCUSSION}

Nowadays, various instruments are used in the literature to assess fatigue, but most of them are only applied to adults and not all of them are specific or have been validated in cancer patients. For the child-juvenile age range, five instruments can be mentioned that assess fatigue: Fatigue Scale-Child (FS-C); Fatigue Scale-Adolescent (FS-A); Fatigue Scale-Parent-PFS; Fatigue Scale-Staff (SFS), developed by the same group of researchers ${ }^{17}$ and the PedsQL Multidimensional Fatigue Scale, with versions for self-reporting by children and adolescents, divided per age group, and reporting by parents. ${ }^{9}$

The lack of references on the validation of the instrument used is a factor that needs to be taken into account. It should be reminded that, methodologically, the instruments should be validated for the context they will be used in, with a view to guaranteeing the reliability of the collected data. Construct validity is one of the most important ways to assess the psychometric characteristics of an instrument and, although it is a complex process that is difficult to determine, an instrument with good construct validity guarantees the assessment of the theory under investigation. ${ }^{35}$
Besides the importance of validating instruments, evidence suggests that, despite the increasing number of children with fatigue, conceptual gaps remain and further research contributes to refine the concept and contribute to clinical care. ${ }^{36}$

We identified that, in the Brazilian, no fatigue measurement instrument has been validated, although these instruments have been used in two different studies. ${ }^{27,28}$ The PedsQL Multidimensional Fatigue Scale has already been translated to different language, including Brazilian Portuguese, under the coordination of a multidisciplinary team from the Mapi Research Institute. Among other objectives, this non-for-profit organization aims to make available linguistically validated measuring instruments for use in different cultural contexts $^{14}$. The linguistic validation process of this scale involved translation, back translation and semantic validation. ${ }^{14}$ In the literature, no findings have been reported about its psychometric validation for the Brazilian population, nor about the semantic and psychometric validation of the Fatigue Scale-Child and Fatigue Scale-Adolescent in the Brazilian context.

Two instruments were responsible for measuring fatigue in all studies, from different 
perspectives, which exist in self-reporting version for the children and adolescents and reporting by parents and/or health professionals.

Although studies indicate that children and adolescents are the main source to talk about themselves, also due to great disparities among the child, parents and professionals' perception of the child's fatigue, ${ }^{37}$ in certain situations, the parents and professionals are valuable information sources, especially when the children and adolescents are disabled or indisposed due to the set of symptoms triggered by the disease or treatment. In some cases, the disease can cause a variation in cognitive and linguistic levels, making exclusive self-reports hardly reliable; thus, in combination with the parents' reports, they can add important information..$^{38}$ Another aspect that needs to be considered is that the parents know their children well and listen to their complaints. ${ }^{10}$

As regards the number of subjects and their inclusion criteria, various studies analyzed identified the use of research subjects with different types of tumors instead of just one as a study limitation, in view of the fact that a sample with different diagnoses and chemotherapeutic regimens makes it impossible to reach specific conclusions about certain diagnoses and treatment protocols. ${ }^{32}$ Nevertheless, limiting to one type of diagnosis and treatment can also mean limiting the number of participants. The great discrepancy in the number of subjects among the studies should be considered, and this difference may have occurred due to the difficulty to find a number of children and/ or adolescents who complied with the established inclusion criteria. One of the studies justified that the fact of having chosen only children from the same pediatric hospital, using the same treatment protocol, in order to avoid confounding factors, limited the sampling number. It was also highlighted that fatigue should be assessed separately for each type of cancer, but this type of study would entail time and sample difficulties.

\section{FINAL CONSIDERATIONS}

Every day, the health professionals interact with children and adolescents who go through situations of anxiety and discomfort as a result of chronic conditions. The responsibility to promote the relief of these subjects' different symptoms, including fatigue, as well as their comfort, requires the assessment of the physiological and behavioral aspects that influence the children and adolescents' condition. Accurate and valid instruments need to exist that guide actions with a view to comprehensive and effective care delivery.

The absence of Brazilian publications on the theme demonstrates a knowledge gap, a fact that justifies the underreporting of fatigue in children and adolescents with cancer. Therefore, knowledge production and research development are relevant to provide available instruments for the assessment of pediatric oncology patients. In conclusion, it is important to develop studies about the theme and apply them in professional practice with a view to enhancing the evidence on these symptoms and furthering the quality of life of child and adolescent cancer victims. To act in this context, health professionals, mainly nursing professionals, need knowledge and skills with a view to a better understanding of how the disease and the course of treatment affect pediatric oncology patients in a global sense.

\section{REFERENCES}

1. Mota DDCF, Pimenta CAM. Fadiga em pacientes com câncer avançado: conceito, avaliação e intervenção. Rev. bras. cancerol. 2002 Out-Dez; 48(4):577-83.

2. Menezes MFB, Camargo TC. A fadiga relacionada ao câncer como temática na enfermagem oncológica. Rev Latino-am Enfermagem. 2006 Maio-Jun; 14(3):442-7.

3. Hinds PS, Hockenberry M, Rai SN, Zhang L, Razzouk BI, Cremer L, et al. Clinical field testing of an enhanced-activity intervention in hospitalized children with cancer. J Pain Symptom Manag. 2007 Jun; 33(6):686-9.

4. Jalmsell L, Kreicbergs U, Onelov E, Steineck G, Henter J. I. Symptoms affecting children with malignancies during the last month of life: a nationwide follow-up. Pediatrics. 2006 Apr; 117(4):1314-20.

5. Theunissen JM, Hoogerbrugge PM, Van Achterberg T, Prins JB, Vernooij-Dassen MJ, Van Den Ende CH. Symptoms in the palliative phase of children with cancer. Pediatr Blood Cancer. 2007 Aug; 49(2)160-5.

6. Wolfe J, Grier HE, Klar N, Levin SB, Ellenbogen JM, Salem-Schatz S, et al. Symptoms and suffering at the end of life in children with cancer. N Engl J Med. 2000 Feb; 342(5):326-33.

7. Gibson F, Garrett M, Richardson A, Edwards J, Sepion B. Heavy to carry: a survey of parents and healthcare professionals perceptions of cancer related fatigue in children and young people. Cancer Nurs. 2005 Jan-Feb; 28(1):27-35.

8. Wu HS e McSweeney $\mathrm{M}$. The assessment and measurement of fatigue in people with cancer. In: 
Nunes MDR, Silva MCM, Rocha EL, Lima RAG, Nascimento LC

Armes J, Krishnasamy M, Higginson I, editors Fatigue in cancer. Oxford: Oxford University; 2004. p.193-221.

9. Varni JW, Burwinkle TM, Katz ER, MeesKe K, Dickinson P. The PedsQL(TM) in pediatric cancer - Reliability and validity of the Pediatric Quality of Life Inventory (TM) Generic Core Scales, Multidimensional Fatigue Scale, and Cancer Module. Cancer. 2002 Apr; 94(7): 2090-106.

10. Yeh $\mathrm{CH}$, Chiang YC, Lin L, Yang CP, Chien LC, Weaver MA, et al. Clinical factors associated with fatigue over time in paediatric oncology patients receiving chemotherapy. Br J Cancer. 2008 Jul; 99(1):23-9.

11. Hockenberry-Eaton M, Hinds, P. Fatigue in children and adolescents with cancer: evolution of a program of study. Semin Oncol Nurs. 2000 Nov; 16(4):261-72.

12. Whittemore R, Knafl K. The integrative review: updated methodology. J Adv Nurs. 2005 Dec; 52(5):546-553

13. Mendes KDS, Silveira RCCP, Galvão CM. Revisão integrativa: método de pesquisa para a incorporação de evidências na saúde e na enfermagem. Texto Contexto Enferm. 2008 Out-Dez; 17(4):758-64.

14. PedsQL [página na internet] Lyon (France): PedsQL; 2011. [acesso em agosto 2011]. Disponível em: http:/ / www.pedsql.org

15. Chiang YC, Hinds PS, Yeh $\mathrm{CH}$, Yang $\mathrm{CP}$. Development and psychometric testing of a Chinese version of the Fatigue Scale-Children in Taiwan. J Clin Nurs. 2008a May; 17 (9):1201-10.

16. Hinds PS, Yang J, Gattuso JS, Hockenberry M, Jones $\mathrm{H}$, et al. Psychometric and Clinical Assessment of the 10-Item Reduced Version of the Fatigue ScaleChild Instrument. J Pain Symptom Manag. 2010 Mar; 39(3):572-8.

17. Hockenberry MJ, Hinds PS, Barrera P, Bryant R, Adams-McNeill J, Hooke C, et al. Three instruments to assess fatigue in children with cancer: The child, parent and staff perspectives. J Pain Symptom Manag. 2003 Apr; 25(4):319-28.

18. Chiang YC, Hinds PS, Yeh CH, Yang CP, Srivastava DK. Reliability and validity of the Chinese version of the Fatigue Scale-Adolescent. Cancer Nurs. 2008 May-Jun; 31(3): E1-8.

19. Hinds PS, Hockenberry M, Tong X, Rai SN, Gattuso JS, McCartthy K, et al. Validity and reliability of a new instrument to measure cancer-related fatigue in adolescents. J Pain Symptom Manag. 2007 Dec; 34(6): 607-18.

20. Lai JS, Cella D, Kupst MJ, Holm S, Kelly ME, Bode RK, et al. Measuring fatigue for children with cancer: development and validation of the pediatric Functional Assessment of Chronic Illness TherapyFatigue (pedsFACIT-F). J Pediatr Hematol Oncol. 2007 Jul; 29(7): 471-9.
21. Ekti GK, Conk Z. Impact of effective nursing interventions to the fatigue syndrome in children who receive chemotherapy. Cancer Nurs. 2008 JulAug; 31(4): 312-17.

22. Meeske K, Katz ER, Palmer SN, Burwinkle T, Varni JW. Parent proxy-reported health-related quality of life and fatigue in pediatric patients diagnosed with brain tumors and acute lymphoblastic leukemia. Cancer. 2004 Nov; 101(9): 2116-25.

23. Sanford SD, Okuma JO, Pan J, Srivastava DK, West N, Farr L, et al. Gender differences in sleep, fatigue, and daytime activity in a pediatric oncology sample receiving dexamethasone. J Pediatric Psychol. 2008 Apr; 33(3): 298-306.

24. Perdikaris P, Merkouris A, Patiraki E, Tsoumakas $\mathrm{K}$, Vasilatou-Kosmidis E, Matziou V. Evaluating cancer related fatigue during treatment according to children's, adolescents' and parents' perspectives in a sample of Greek young patients. Eur J Oncol Nurs. 2009 Dec; 13(5): 399-408.

25. Vallance K, Liu W, Mandrell BN, Panetta JC, Gattuso JS, Hockenberry M, et al. Mechanisms of dexamethasone-induced disturbed sleep and fatigue in paediatric patients receiving treatment for ALL. Eur J Cancer. 2010 Jul; 46(10): 1848-55.

26. Zupanec S, Jones H, Stremler R. Sleep habits and fatigue of children receiving maintenance chemotherapy for all and their parents. J Pediatric Oncol Nurs. 2010 Jul-Aug; 27(4):217-28.

27. Silva, RZM. Avaliação da fadiga em sobreviventes de câncer infantil e correlação com sintomas depressivos, distúrbios do sono e variáveis [dissertação]. São Paulo: Fundação Antônio Prudente. 2009.

28. Kurashima AY. Pacientes pediátricos oncológicos fora de possibilidades terapêuticas curativas: avaliação de sintomas, depressão, fadiga e qualidade de vida [tese]. São Paulo (SP): Fundação Antônio Prudente. 2007.

29. Hinds PS, Hockenberry MJ, Gattuso JS, Srivastava DK, Tong X, Jones $\mathrm{H}$, et al. Dexamethasone alters sleep and fatigue in pediatric patients with acute lymphoblastic leukemia. Cancer. 2007 Nov; 110(10):2321-30.

30. Hinds PS, Hockenberry MJ, Rai SN, Zhang L, Razzouk BI, McCarthy K, et al. Nocturnal awakenings, sleep environment interruptions, and fatigue in hospitalized children with cancer. Oncol Nurs Forum. 2007 Mar; 34(2):393-402.

31. Yeh $\mathrm{CH}$, Man Wai JP, Lin US, Chiang YC. A pilot study to examine the feasibility and effects of a home-based aerobic program on reducing fatigue in children with acute lymphoblastic leukemia. Cancer Nurs. 2011 Jan-Feb; 34(1): 3-12.

32. Erickson JM, Beck SL, Christian BR, Dudley W, Hollen PJ, Albritton KA, et al. Fatigue, sleep-wake disturbances, and quality of life in adolescents 
receiving chemotherapy. J Pediatr Hematol Oncol. 2011 Jan; 33(1): E17-25.

33. Tomlinson D, Hinds PS, Bartels U, Hendershot E, Sung L. Parent reports of quality of life for pediatric patients with cancer with no realistic chance of cure. J Clin Oncol. 2011 Jan-Feb; 29(6): 639-45.

34. Perdikaris P, Merkouris A, Patiraki E, Papadatou D, Vasilatou-Kosmidis H, Matziou V. Changes in children's fatigue during the course of treatment for paediatric cancer. Int Nurs Rev. 2008 Dec; 55(4): 412-19.

35. Urbina S. Fundamentos da testagem psicológica. Porto Alegre (RS): Artmed; 2007.
36. McCabe, M. Fatigue in children with long-term conditions: an evolutionary concept analysis. J Adv Nurs. 2009; 65(8): 1735-45.

37. Hinds PS, Hockenberry-Eaton, M, Gilger EBSN, Kline NMS, Burleson, Cindy BSN, et al. Comparing patient, parent, and staff descriptions of fatigue in pediatric patients. Cancer Nurs. 2000; 22(4): 277-88.

38. Chang PC, Yeh CH. Agreement between child selfreport and parent proxy-report to evaluate quality of life children with cancer. Psychooncology. 2000; 14:25-134. 